\section{Ks. Piotr Roszak}

Universidad de Navarra, Pampeluna; UMK, Toruń

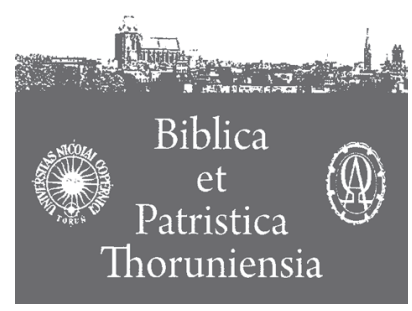

5 (2012) ISSN 1689-5150

\title{
Beato z Liébany i mozarabskie komentarze do Apokalipsy*
}

\section{Beato de Liébana and mozarabic commentary on Apocalypse}

Słowa kluczowe: Beato z Liébany, mozarabowie, arianizm, adopcjanizm, ryt hiszpańsko-mozarabski.

Key words: Beato de Liébana, mozarabs, arianism, adoptionism, hispanic-mozarabic rite.

$\mathrm{M}$ ozarabowie stanowią zagadkową i dotychczas mało znaną pod kątem teologicznym grupę społeczną ${ }^{1}$. Zazwyczaj są przedstawiani w perspektywie ważnej roli, którą odegrali w przeniesieniu dorobku starożytnego chrześcijaństwa hiszpańskiego, ocalonego dzięki ich wytrwałości w trudnych czasach islamskiej dominacji, w czasy nowożytne ${ }^{2}$. Jako „walcząca mniejszość”, niespokojna i twórcza, toczyli jednak walkę o ocalenie swej tożsamości zagrożonej pójściem na kompromis, porzuceniem chrześcijańskich zwyczajów i liturgii, która narażona była na szczególne niebezpieczeństwo jako że stanowiła

W artykule wykorzystano informacje zdobyte w ramach realizowanego grantu „Chrystus vs Mahomet. Chrystologia mozarabska w świetle źródeł liturgicznych rytu hiszpańskiego" sfinansowanego ze środków Narodowego Centrum Nauki przyznanych na podstawie decyzji numer DEC-2011/01/D/HS1/00712.

1 P. Roszak, Mozarabowie - niespokojna mniejszość. Liturgia mozarabska jako projekt duchowości czasów „bycia w mniejszości” w kontekście „Brewiarza Gotyckiego, „Teologia i Człowiek" 13 (2009), s. 79-98.

2 Por. D. Urvoy, La pensée religieuse des Mozarabes face à l'Islam, „Traditio” 39 (1983), s. $419-432$. 
ich kulturowo-religijny wyróżnik oraz ze względu na siłę zakorzenienia w ich chrześcijańskiej tożsamości³.

Bez wątpienia mozarabska liturgia miała świadomość wyzwania czasów, które polegało na trosce o ocalenie owego continuum, łączności z wcześniejszą tradycją chrześcijańską doby wizygockiej, która przyniosła owoce w postaciach wielkich hiszpańskich ojców Kościoła (takich jak Izydor z Sewilli czy Ildefons z Toledo). Ich wysiłki, możliwe do opisania jako pewnego rodzaju sztuka - ars ${ }^{4}$, obejmują skupienie bacznej uwagi na lekturze Pisma Świętego w czasie sprawowanej liturgii, a zwłaszcza - co znamienne - na księdze Apokalipsy5 ${ }^{5}$. Szczególną rolę w tym względzie odegrał komentarz autorstwa Beato z Liébany (ok. +799), który zyskał wielką popularność w kolejnych wiekach, o czym świadczą zachowane liczne kopie tego dzieła oraz powstała na jego kanwie wyjątkowa sztuka miniaturzystów, niemożliwa do pomylenia z żadną inną ${ }^{6}$. Stworzyli ją zakonnicy, którzy przybyli do klasztorów północnej Hiszpanii z terenów dzisiejszej Andaluzji zajmowanej wówczas przez Arabów, z tego powodu określani przez współziomków mianem „mozarabów” ną nazwą Beatos i stały się swoistym gatunkiem pewnej interpretacji Księgi Apokalipsy, tworzącej harmonijną jedność (również hermeneutyczną) ze sztuką iluminatorską. W kontekście sytuacji historyczno-społecznej panującej na Półwyspie Iberyjskim zyskały szczególny wydźwięk, gdyż w jakiejś mierze podejmowały się próby przedstawienia sytuacji chrześcijan w perspektywie wizji przekazywanych przez Apokalipsę. Komentarze Beato eksponują zwłaszcza realność zła sianego przez Antychrysta, mężny opór wobec niego wybranych świadków Jezusa i dokonują szczególnego odczytania historii w kluczu nadziei na zwycięstwo Chrystusa, który przybędzie jako ostatecznie triumfujący, aby nagrodzić wytrwałość i cierpliwość mozarabskich chrześcijan. Dlatego w licznych miniaturach zwycięski Baranek jest zawsze dużo mniejszy od bestii i dzi-

3 M. Diaz, Los mozárabes. Una minoría combativa, w: C. Aillet, M. Penelas, P. Roisse, ¿Existe una identidad mozárabe? Historia, lengua y cultura de los cristianos de al-Andalus (siglos IX-XII), Casa de Velázquez, Madrid 2008, s. 7-8.

4 Pisałem o tym w P. Roszak, Ars identitatis. Casus mozarabski a hiszpańskie doświadczenie graniczności, w: Przyszłość cywilizacji Zachodu. Cywilizacje wobec multikulturalizmu (w druku).

5 Por. X. Picaza, Apocalíptica judía y cristiana. Prehistoria y símbolos básicos del Apocalipsis, w: En torno al Apocalispsis, BAC, Madrid 2001, s. 3-112.

6 M. Mentré, La peinture mozarabe, Presses universitaires de Sorbonne, Paris 1984; C. Nordenfalk, L'Enluminure au Moyen Âge, Ed. Albert Skira, Genève 1988; Y. Yarza, La miniatura medieval en la península ibérica, Nausíca, Murcia 2007.

7 G. Menéndez Pidal, Mozárabes y asturianos en la cultura de la Alta Edad Media, Boletín de la Real Academia de la Historia 134, Madrid 1954. 
kich zwierząt, które symbolizują przeciwników Syna Bożego. Jest to dysproporcja, która staje się czytelną aluzją do braku równowagi sił między wyznawcami Chrystusa a muzułmanami na Półwyspie Iberyjskim, ale także pozorną, traktowaną jedynie wedle ludzkich miar, sytuację dobra i zła na świecie.

\section{Beato z Liébany i jego komentarz do Apokalipsy}

Niewiele posiadamy szczegółowych informacji o Beato, a zdecydowanie lepszym przewodnikiem po jego życiu, jak podkreślają badacze, są jego własne dzieła niż późniejsze żywoty, jak choćby słynne Martyrologium Hispanum autorstwa Juana Tamayo de Salazara $(+1662)^{8}$. Żywot Beato zawarty w tym dziele nie wzbudza bowiem zaufania wśród historiografów ze względu na wiele błędów i fikcji. Co więc można dowiedzieć się o życiu tego kantabryjskiego mnicha na podstawie jego dzieł oraz innych świadectw historycznych jego czasów?

Beato w oczach sobie współczesnych uchodził za najbardziej światłego człowieka-erudytę północnych królestw Iberii. Swoje wykształcenie pogłębił zapewne w karolińskiej Francji, do której często podróżował, aby po powrocie do Asturii stać się motorem przemian intelektualnych na tamtych ziemiach, zwłaszcza z zakresu historiografii (o czym świadczą Annales, Chronicon Iriense, Chronicon Compostelano), co nie pozostaje bez znaczenia dla naszych badań nad Apokalipsą ${ }^{9}$. Osiadł w klasztorze Santo Toribio de Liébana, gdzie rozwinął bogatą twórczość teologiczną. Wiadomo, że poświęcał swój wysiłek nade wszystko na studium Pisma Świętego, dziedzinę, w której (jak podaje Alkuin z Jorku) był ekspertem. Zapisał się w historii również jako autor hymnu O Dei Verbum ku czci św. Jakuba Starszego, który szybko stał się częścią oficium liturgicznego ku czci apostoła. Najprawdopodobniej to właśnie Beato był inicjatorem uznania św. Jakuba za patrona odradzających się wówczas chrześcijańskich królestw północnych, znajdujących się w trudnej sytuacji politycznej zarówno wewnętrznej, ale i zewnętrznej w obliczu silnego naporu arabskiego. Nie bez znaczenia jest zatem fakt, że w komentarzu do Apokalipsy potwierdza działalność misyjną św. Jakuba na terenie Hiszpanii.

8 J. Williams, Purpose and Imaginery in the Apocalypse Commentary of Beatus of Liébana, w: R. Kenneth, B. McGinn, The Apocalypse in the Middle Ages, Cornell University, s. 217. Juan Tamayo przypisuje mu święto 19 lutego. W sporze między Elipando a Beato Juan Tamayo przyrównuje Beato do Dawida, a Elipando do Goliata.

9 S. Bodelón, Literatura latina de la Edad Media en España, Ediciones AKAL, Madrid 1989, s. 41. 
Wielu znawców tematu skłania się ku przekonaniu, że Beato był chrześcijaninem, który emigrował (jak wielu wówczas), być może jeszcze jako dziecko, z południa Półwyspu Iberyjskiego opanowanego przez muzułmanów, za czasów wypraw króla Alfonsa I, by znaleźć się z dala od prześladowań w królestwie Asturii ${ }^{10}$. Wyjaśniałoby to tak dobrą znajomość źródeł patrystycznych, o którą byłoby trudno w niewielkiej Asturii czy Kantabrii. Do naszych czasów przetrwał list Alkuina z Jorku do Beato, datowany między 797 a 800 r., do którego zwraca się z tytułem opat ${ }^{11}$ i jest właściwie ostatnim dokumentem, dzięki któremu można w przybliżeniu ustalić datę śmierci naszego autora.

Zamiarem Beato nie było napisanie własnego komentarza, ale raczej pewnej summy egzegetycznej do Apokalipsy. Dlatego rzadko przedstawia swoje własne poglądy, a nawet ukrywa je w przemyślanej strukturze komentarza, w którym zestawia ze sobą cytaty z Pisma Świętego i innych autorów patrystycznych, dziś znanych dla nas nieraz jedynie dzięki Beato. W literaturze egzegetycznej wieków średnich przypominało to tzw. catenae, a więc łańcuchy cytatów biblijnych, zestawianych ze sobą ${ }^{12}$. Niemniej jednak jest to dzieło niezwykle oryginalne, a intencja jego autora zdecydowanie wyróżnia się od wcześniejszych traktatów egzegetycznych dotyczących Apokalipsy, ponieważ Beato nie idzie tropem św. Izydora i jego idei komentarza jako opus ex veteris lectionis recordatione collectum, lecz dokonuje selekcji, uporządkowania swoich źródeł i nadaje im własny styl, aby przedstawić swoją interpretację ${ }^{13}$. Jest to myślenie w „przestrzeni źródeł”, dokonujące odważnych cięć (nieraz całych sekcji), aby nie zgubić głównego wątku oraz aby wprowadzić czytelnika w lekturę pomagającą przeżywać tajemnice Apokalipsy w czasie obecnego, mozarabskiego - ziemskiego życia.

Zdaniem badaczy zapewne już źródłowy komentarz Beato zawierał szereg iluminacji, ale nie zachowały się do naszych czasów. Kopie szybko rozpowszechniły się w Hiszpanii, o czym świadczy wielka liczba manuskryptów. Przyczyniła się również do tego tradycja liturgiczna, którą dla rytu hiszpańskiego ustanowił Sobór Toledański IV (633 r.) w kan. 17, zapewne nie bez inspiracji św. Izydora z Sewilli, aby odczytywać Księgę Apokalipsy podczas wszystkich mszy świętych

10 A. del Campo, Introducción, w: Beato de Liébana, Obras completas y complementarias, vol. I, Biblioteca de Autores Cristianos, Madrid 2004, s. 22.

11 M. Adelaida, A. Sanz, La Hispania Visigótica y Mozárabe: dos épocas en su Literatura, Ediciones Universidad de Salamanca, Salamanca 2010, s. 232.

12 Do najbardziej znanych dzieł tego typu należy bez wątpienia tzw. Catena Aurea św. Tomasza z Akwinu do czterech Ewangelii.

13 M. Baloira, Originalidad y apropiaciones en el Comentario al Apocalipsis de Beato de Liébana, Actas del I Simposio de latín cristiano, Salamanca 1990, s. 174. 
odprawianych od świąt wielkanocnych do Pięćdziesiątnicy ${ }^{14}$. Nie bez znaczenia przy tym był kontekst polemiki z arianizmem, którego zwolennicy negowali kanoniczność księgi Apokalipsy, podkreślającej tak zdecydowanie bóstwo Chrystusa ${ }^{15}$. W ten sposób interesujący nas komentarz autorstwa Beato był również powrotem do głębokiej tradycji liturgii hiszpańskiej i jej kontynuacją w nowych realiach historycznych ${ }^{16}$.

Cel komentarza jest zbliżony do przesłania samej Księgi Apokalipsy i sytuacji siedmiu Kościołów w Azji. Analogiczna dekadencja kościołów hiszpańskich wobec postępującej islamizacji kraju, który może się poszczycić chrześcijaństwem sięgającym apostołów i ich uczniów, budzi zmartwienie Beato. Ale nie bez znaczenia pozostają poglądy millenarystyczne autora, że jego świat znajduje się w bliskości końca świata. Nie zapominajmy również, że skoro był to tekst odczytywany liturgicznie w okresie wielkanocnym, to wpisywał się w logikę lectio divina: bardziej niż materialne słuchanie słów, chodziło w niej o uczuciową interioryzację, w której kluczową rolę odegrały miniatury. Miały przygotować lekturę duchową.

\subsection{Struktura i źródła komentarza Commentarius in Apocalipsim}

Nie dotarło do naszych czasów nie tylko oryginalne dzieło Beato, ale także żadna z kopii z jego czasów. Najstarszy manuskrypt pochodzi z końca IX wieku, bogato ilustrowany i po dziś dzień przechowywany w klasztorze w Silos. Aktualnie istnieją 32 manuskrypty komentarza, wliczając również te zachowane we fragmentach, przy czym warto pamiętać jeszcze o 6 zagubionych już w epoce nowożytnej, o których posiadamy informacje ${ }^{17}$. Komentarz do Apokalipsy już za życia Beato posiadał trzy recenzje: jak proponuje H. Sanders, pierwszą w 776 roku, drugą w 784 i ostateczną dwa lata później. Dzieło Beato było szcze-

14 Nie ulega wątpliwości dogmatyczno-liturgiczny impuls rytu hiszpańsko-mozarabskiego na ostateczny kształt komentarza Beato. Por. P. Martinez-Saiz, El tiempo pascual en la liturgia hispánica. Desarrollo, esctructura y contenido reológico, Madrid 1969. Nakazu tego przestrzegano zwłaszcza w środowisku klasztornym, a pomijanie lektury Apokalipsy zagrożone było specjalnymi karami.

15 Świadczy o tym tzw. Liber Commicus, a więc odpowiednik lekcjonarza, w liturgii hiszpańsko-mozrabskiej, co w tradycji rzymskiej odpowiada cyklowi „C”.

16 Por. A. Girbes, Victoria de Cristo sobre la muerte en los textos eucarísticos de la octava pascual hispánica, „Aan” 19 (1972), s. 11-84; J. Gilbert, El significado de la expresión 'Pascha' en la liturgia hispánica, „ELitur” 91 (1977), s. 3-31, 132-45.

17 Por. A. Mundó, M. Sánchez, El comentario de Beato al Apocalipsis: catálogo de los códices, Biblioteca Nacional, Madrid 1976. 
gólne popularne w średniowieczu (stąd często kopiowane), ale nie doczekało się publikacji aż do 1770 roku, gdy augustynianin, Enrique Flórez, wydał drukiem komentarz, tytułując go w następujący sposób: Sancti Beati, presbyteri hispani libanensis, in Apocalypsin, ac plurimas utriusque foederis pagina commenataria, ex veteribus, nonnullisque desideratis Patribus, mille retro annis collecta, nunc prima edita. Natomiast pierwsze wydanie krytyczne to zasługa H.A. Sandersa ${ }^{18}$ i jego publikacji z 1930 roku, a po nim nastąpiło, określane jako modelowe, wydanie E. Romero-Pose ${ }^{19}$ z 1985 roku.

Beato dzieli komentarz do Apokalipsy na $12 \mathrm{ksiąg}$, a te na 68 sekcji, nazywanych storiae ${ }^{20}$. Były to wyodrębnione jednostki tekstu Apokalipsy (historia) wraz z towarzyszącą im ilustracją, które liczyły od kilku po najwyżej 18 wersów. Po nich następowało explanatio suprascriptae historiae, wyjaśnienie wiersz za wierszem, oparte na bezpośrednich cytatach z patrystycznych komentarzy do Apokalipsy zwłaszcza: Hieronima, Augustyna, Grzegorza Wielkiego, Ambrożego, Fulgencjusza, Ireneusza, Tychomiusza, Apringiusza, Izydora z Sewilli, Grzegorza z Elwiry, ale także wielu innych ${ }^{21}$.

Najważniejszym jednak źródłem dla Beato były komentarze afrykańskiego Tychoniusza (gdy już porzucił donatyzm), choć zdaniem niektórzy badaczy (B. Steinhauser ${ }^{22}$ ) nie idzie w czysty sposób za myślą Tychomiusza. Niemniej jednak to ten właśnie teolog afrykański wywarł największy wpływ na Beato: korzysta z dokonanej przez niego strukturyzacji na dwanaście ksiąg, opiera się na łacińskim tekście Apokalipsy, którym posługiwał się Tychomiusz (nie jest to ani Vetus Latina ani Vulgata) i stosuje się do reguł jego egzegezy. Mając to na względzie, nie mogą dziwić pojawiające się w komentarzu tzw. "passusy afrykańskie” - chodzi o te fragmenty komentarza Beato, które dotyczą wydarzeń społeczno-politycznych w Afryce, należących do przeszłości, a w komentarzu traktowanych jako współczesne (z charakterystycznym nunc). Nie wynika to z ignorancji Beato, lecz świadomej opcji egzegetycznej, związanej z ideą „reka-

18 H. Sanders, Beati in Apocalipsin libri duodecim, Papers and Monographs of the American Academy in Rome, Roma 1930.

19 E. Romero-Pose, Sancti Beati a Liebana Commentarius in Apocalipsin, 2 vol., Roma 1985.

20 W poniższych analizach teologicznych opieram się na współczesnym wydaniu komentarza: J. Gonzalez-Echegaray, A. del Campo, L. Freeman, Beato de Liebana. Obras completas y complementarias, vol. I, Biblioteca de Autores Cristianos, Madrid 2004, s. 32-640.

21 Szerzej omawia źródła komentarza Beato do Apokalipsy - S. Alvarez, La importancia de los comentarios de Beato en la historia de la literatura cristiana, „Compostellanum” 33 (1988), s. 53-91.

22 Por. B. Steinhauser, The Apocalypse Commentary of Tyconius: A History of Its Reception and Influence, Frankfurt am Main 1987, s. 141-196. 
pitulacji”, o której będzie mowa poniżej. Mnich z Liébany ma na myśli prześladowania, które wielokrotnie przeżywał Kościół afrykański, zarówno ze strony władz rzymskich, jak i cierpiąc w wyniku herezji: donatyzmu i arianizmu ${ }^{23}$. W pewien sposób mówią one o przeżywanym w nunc czasów Beato podobnym prześladowaniu i trudnościach.

Zwraca uwagę niewielki rozmiar ostatnich ksiąg komentarza w porównaniu do rozległości, z którą traktuje autor zwłaszcza pierwsze rozdziały Apokalipsy. Być może wynika to $\mathrm{z}$ faktu braku materiału źródłowego, który pozostawia wrażenie skromności.

Na końcu swego komentarza Beato umieszcza definicję „kodeksu” i „księgi", które czerpie z Etymologii św. Izydora z Sewilli oraz pochodzący z tego samego dzieła fragment dotyczący stopnia pokrewieństwa. Całość zamyka komentarz św. Hieronima do księgi Daniela, a więc apokalipsy starotestamentalnej, który włącza Beato do swojego dzieła przy pracy nad trzecią, ostatnią, edycją swego komentarza ${ }^{24}$. Dzieło Beato jest niezwykłe również z tego powodu, że nie odnosi się wcale do powstających za jego czasów komentarzy egzegetycznych poświęconych Apokalipsie, ale decyduje się na bezpośredni kontakt ze źródłami patrystycznymi.

\subsection{Prologi}

Olbrzymie dzieło Beato (współczesne wydanie liczy blisko tysiąc stron ${ }^{25}$ ) zostało poprzedzone czteroma prologami. Pierwszy, autorstwa samego Beato, ukazuje parenetyczny zamiar traktatu, jego charakter kompilacyjny oraz eklezjologiczne przesłanie. Wyjaśnienia Apokalipsy zebrane od Ojców Kościoła miały ukoić wątpliwości duchowe wiernych, odczytać we właściwym kluczu spotykające ich trudności i szczególne zdarzenia historyczne. Jednym z nich był dramatyczny koniec chrześcijańskiego królestwa Wizygotów, a także niespodziewana inwazja muzułmańska ${ }^{26}$. Ten wstęp Beato kończy jego dedykacja

23 Trzeba pamiętać, że wpływ chrześcijaństwa afrykańskiego na hiszpańskie sięga początków ewangelizacji Półwyspu Iberyjskiego, gdy najprawdopodobniej misjonarze chrześcijańscy pochodzili właśnie z tej części imperium rzymskiego.

24 M. C. Vivancos, Consideraciones históricas y codícológicas en torno al Beato de Silos, w: Beato de Liébana. Códice del Monasterio de Santo Domingo de Silos, Moleiro Editor, Barcelona 2003, s. 20.

25 Chodzi o wspominane już wyżej Sancti Beati a Liebana Commentarius in Apocalypsin, 2 vol., Roma 1985.

26 L. Peñarroja, Cristianos bajo El Islam. Los mozárabes hasta la reconquista de Valencia, Monografias historicas 4, Gredos, Madrid 1993. 
(występująca jednak jedynie w ostatnim wydaniu komentarza do Apokalipsy) Heteriuszowi, biskupowi Osmy i jednocześnie swojemu uczniowi oraz współautorowi innego dzieła, jakim był Apologeticus. W tym wszystkim wzoruje się na wstępach św. Izydora (zwłaszcza z De ecclesiasticis officis, De ortu et orbitu Patrum czy De fide catholica). Drugim jest prolog przypisywany św. Hieronimowi, poprzedzający księgę Apokalipsy w Wulgacie - zwyczaj przytaczania tego prologu istniał aż do późnego średniowiecza (czyni tak jeszcze choćby św. Tomasz z Akwinu ${ }^{27}$ ). Trzecim prologiem jest wstęp napisany również przez św. Hieronima tym razem do komentarza do Apokalipsy autorstwa Wiktoryna.

Tę część komentarza zamyka czwarty prolog, który jest bardziej ogólnym streszczeniem treści Commentarius in Apocalypsin, który w pierwszym wydaniu Floreza został określony jako Summa dicendorum. Nic dziwnego, ponieważ istotnie stanowi podsumowanie głównych linii interpretacyjnych komentarza, które mają charakter wybitnie eklezjologiczny. To właśnie tutaj Beato przypomina, że siedem kościołów Apokalipsy to obraz Kościoła Powszechnego; otwarte drzwi do nieba (Ap 4,2) to Chrystus sam wprowadzający do Kościoła; on też jest owym białym koniem, na którym zasiada jeździec - Chrystus (Ap 6,2). Podobnie Niewiasta obleczona w Słońce (Ap 12,1) to Kościół, w którym jaśnieje zmartwychwstały Chrystus. Wszystkie obrazy eklezjologiczne mają umocnić wierzących, aby nie oddawali swego ducha „światu” (nienawidzącego Chrystusa), lecz zachęcali się wzajemnie do postawy wierności. Ucisk Kościoła, jego ofiara składana za niezłomność w prześladowaniach, to właściwy dla Beato sposób lektury księgi Apokalipsy.

\subsection{Tło chrystologiczne komentarza: spór z arianizmem i adopcjanizmem}

W opinii Menendez y Pelayo, komentarz to także teologiczna odpowiedź, właściwa dla kantabryjskiego charakteru, na pierwsze sygnały nowej kontrowersji, którą był adopcjanizm i dlatego zdania formułowane przez Beato są jak wykuwane żelazo ${ }^{28}$. Rodzi się więc na kanwie sporu, który ogniskował teologiczną uwage pod koniec VIII wieku ${ }^{29}$. W 784 roku synod w Sewilli potępia poglądy prezbitera Migencjusza, który głosił teorie antytrynitarne, a jego głównym

27 Por. Św. Tomasz z Akwinu, Wykład Ewangelii św. Jana, Antyk, Kęty 2002 (Prolog).

28 Menendez y Pelayo, Historia de los heterodoxos españoles, t. II, Madrid 1917, s. 134; E. Benito Ruano, Historia de Asturias, Oviedo 1979, s. 106. Por. także S. Bodelón, Literatura latina de la Edad Media en España, s. 138.

29 F.C. Asainz de Robles, Elipando y San Beato de Liébana: Siglo VIII, Aguilar, Madrid [1935]. 
oskarżycielem jest arcybiskup Toledo Elipando ${ }^{30}$. Na kanwie polemiki i zapewne pragnąc podkreślić znaczenie Toledo, hierarcha publikuje symbol wiary, w którym sam jednak oddala się od ortodoksji, wprowadzając niejasne rozróżnienia dotyczące rozumienia człowieczeństwa Chrystusa. Elipando twierdził, że jako człowiek Chrystus powinien być uznawany za przybranego Syna Bożego, co stanowi przynajmniej pojęcie dość niejasne w odniesieniu do osoby Chrystusa (i jedności tej osoby). Nie jest to adopcjanizm w czystej postaci. Swoją opinią na temat natury owej adoptio w odniesieniu do Chrystusa podzielił się ze słynącym z erudycji biskupem Felixem z Urgel, który potwierdza nowe sformułowanie dogmatyczne arcybiskupa Toledo. Jednak już ok. 785 roku Elipando otrzymuje informację, że Heteriusz, biskup Osmy oraz prezbiter nazywany Beato sprzeciwiają się takiemu ujęciu tajemnicy chrystologicznej. W tej sytuacji Elipando decyduje się na napisanie listu do biskupa Ascario z Astorgii i opata Fidela, oskarżając obu swoich oponentów. Ci zaś zapoznawszy się z listem formują swoje uwagi w Apologetyku, prezentując błędy w refleksji teologicznej Arcybiskupa Toledo. Beato więcej nie weźmie już udziału w sporze, który zakończy się na zwołanym przez Karola Wielkiego synodzie we Frankfurcie (799), w którym główną rolę odegra Alkuin z Jorku i potępienie adopcjanizmu Elipando i Felixa.

Z dzieł Beato można wywnioskować jego pokrewieństwo (a na pewno zainteresowanie) z ideami millenaryzmu: wedle niektórych świadectw historycznych oczekiwał bliskiego końca świata, który wynikał z wnioskowanego na podstawie obliczeń biblijnych czasu, który upłynął od stworzenia (w $800 \mathrm{roku}$ byłoby to 6000 lat jego zdaniem). W liście Elipando spotykamy również anegdotę, którą jednak należy osadzić w kontekście sporu z Beato: pewnego roku (nie wiemy kiedy), Beato zgromadził podczas wigilii paschalnej rzeszę osób, która miała wraz z nim oczekiwać końca świata, mającego nastąpić o poranku. Wydaje się, że jest to jednak retoryczny atak na Beato ze strony obrażonego hierarchy niż realne wydarzenie. Sam Beato w komentarzu zauważa, że „gdy ktoś schodzi z tego świata, wówczas dla niego ma miejsce koniec świata”. Niemniej jednak to uwarunkowanie millenarystyczne winno być wzięte pod uwagę przy interpretacji dzieła.

30 J. C. Cavadini, The last christology in the West. Adoptionism in Spain and Gaul, 785-820, University of Pensylvania Press, Philadelphia 1993. 


\section{Apokaliptyczne miniatury mozarabskie}

Wielkim skarbem i wyróżnikiem kodeksów z komentarzami Beato są ich bogate zdobienia, które występuje w przeważającej większości zachowanych do naszych czasów kopii ${ }^{31}$. Jak podkreślają badacze, iluminacje kodeksów stanowią pewną całość $\mathrm{z}$ ich tekstami, gdyż albo je uzupełniają o nowe aspekty lub wnoszą własne idee. Warto zwrócić uwagę, że sztuka miniaturystyczna jest już znakiem integracji w sobie wielu sprzecznych form. Nie mniej jednak eklektyzm mozarabski nie był zwykłym zestawianiem „obok” siebie, lecz aktem twórczym, który nosił osobiste znamię autorów, nie do pomylenia z innymi ${ }^{32}$.

Przerażający i tajemniczy język Apokalipsy został wyrażony i zinterpretowany w miniaturach towarzyszących komentarzowi Beato, który dzięki temu uchodzi za jeden z najlepiej zbadanych manuskryptów średniowiecznych. Egzotyczny ekspresjonizm miniatur Beatos przypisuje się przenikającym się wpływom różnych tendencji artystycznych, pochodzących zarówno jeszcze z okresu późnorzymskiego, bizantyjskiego, wizygockiego, karolińskiego, ale także muzułmańskiego z Al-Andalus ${ }^{33}$.

\subsection{Geneza miniatur}

Ponieważ miniatury nie odnoszą się do komentarza, a wprost do tekstu Księgi Apokalipsy, wielu badaczy jest zdania, że zostały skopiowane z wcześniejszych ksiąg z tekstem Apokalipsy jeszcze z ery wizygockiej. Niektórzy badacze wykazują zależności od zagubionego dzisiaj komentarza Tychomiusza, do którego często odwołuje się Beato, choć inni (jak choćby Neuss) wskazują na znaczące różnice, które oddzielają „literalnego" w swej interpretacji Apokalipsy Beato od

31 Por. J. Yarza, Apocalipsis en España. La iluminación de los Beatos, w: Beato de Liébana. Munuscritos iluminados, Barcelona 1998, s. 224nn.

32 Najbardziej znani wśród miniaturzystów to Magio i jego uczeń Emeterio, twórcy szkoły w Tabara, ale także Florencjusz i Vigila.

33 Określenie „mozarabskie” w stosunku do komentarzy Beato, co warto w tym miejscu przypomnieć, wiąże się z jednej strony z wielką rolą, jaką odegrali mnisi mozarabscy emigrujący z południa półwyspu i tworzący Beatos w klasztorach królestwa Leon (zwł. Palencia, Zamora). Choć nie do końca jesteśmy w stanie wykazać źródłowo tego rodzaju zależność, to jednak nie ulega wątpliwości, że dzieła te powstają w kontekście panującego stylu mozarabskiego w kulturze, przypadającego na ten właśnie czas historii, między okresem preromańskim i właściwą epoką romańską. 
duchowego w swej egzegezie afrykańskiego Tychomiusza ${ }^{34}$. W każdym razie wydaje się niemal pewne, że od początku ilustracje znajdowały się w kodeksach: nie tylko możemy odnaleźć aluzyjne formuły do miniatur w samym tekście komentarza, ale także w ostatnim wersecie kodeksu mówi się o duchowym znaczeniu tych ilustracji, które mają wzmocnić ducha czytającego ${ }^{35}$. Choć miniatury niosą na sobie znamię każdego z artystów, ślady trendów danej epoki, niemniej jednak stanowią jednolity projekt ikonograficzny, który czytelnie odwołuje się do pewnego prototypu.

Charakterystyczną cechą miniatur mozarabskich z Beatos jest ich zdolność syntezy: łączą ze sobą tematy, które w tekście Apokalipsy nie są ze sobą powiązane i tylko $\mathrm{z}$ wielką trudnością można je odnaleźć przez wspólne motywy. Miniatury cechuje ekspresja oparta na silnej linii, rozwijają się płasko, nie ma żadnych rozjaśnień, prześwitów, intensywnych kolorów czy perspektyw przestrzennych. Wszystko to jednak wpływa na zwiększenie dramatyzmu przedstawianych scen i niezwykłą ich ekspresyjność. Figury i kształty pojawiają się stopniowo, ludzkie zaś postaci są przedstawiane $\mathrm{w}$ wymownych strojach oraz co właściwe dla sztuki romańskiej, z wyróżnieniem rąk i oczu, które mają potęgować napięcie duchowe. Postaci są przedstawiane na bogatym tle chromatycznym, sprawiającym wrażenie idyllicznego czy podzielonego na kilka obszarów o różnych, silnych kolorach i równie przebijających ${ }^{36}$.

Niekiedy przedstawiane sceny apokaliptyczne są ubogacane nawiązaniami do innych scen biblijnych (zarówno ze Starego, jak i Nowego Testamentu). Często w Beatos pojawiają się miniatury obrazujące siedem kościołów Azji, wizję Baranka objawiającego się sprawiedliwym czy obraz niebieskiej Jerozolimy przedstawianej ze swymi dwunastoma bramami (z typowymi zamknięciami).

Podsumowując, komentarz Beato posiada 108 ilustracji: $68 \mathrm{z}$ nich odwołuje się do narracji Apokalipsy i dlatego są umieszczone bezpośrednio za storiae; 7 ilustracji bazuje na samym komentarzu (Mapamundi, Apostołowie, Arka Noego etc.). Do tego trzeba dodać 8 miniatur ewangelistów i ich dzieł, a także 14 obrazów przedstawiających genealogię Jezusa oraz 11 innych iluminacji, które odwołują się do komentarza do księgi Daniela napisanego przez Hieronima i dołączonego przez Beato do swego dzieła.

34 J. Williams, The Ilustrated Beatus. A Corpus of the Illiustrations of the Commentary on the Apocalypse, vol. I, Harvey Miller Publishers, London 1994.

35 C. Romero de Lecea, Trompetas y citaras en los codices de Beatio de Liebana, Real Academia de Bellas Artes, Madrid 1977, s. 34-36.

36 E. Bolman, De coloribus. The Meaning of Color in Beatus Manuscripts, „Gesta” 38 (1999), s. 22-34. 


\subsection{Analiza teologiczna miniatur}

Apokalipsa przedstawia wizję triumfu nad złem, które utożsamia się z fałszywymi prorokami i autorytetami, które chcą zająć miejsce samego Boga. Kiedy Beato pisze swój komentarz do tej księgi, wydaje się oczywiste, że odniesie się do historycznych realiów panujących na Półwyspie Iberyjskim ${ }^{37}$. W owym czasie konsolidujące się dopiero królestwo Asturii musi już stawić czoła potężnemu emiratowi arabskiemu. Odczytywanie Apokalipsy w tym kontekście oznacza wskazanie na ostateczne zwycięstwo, które czeka wiernych Krzyżowi. Skupimy teraz uwagę na kilku najbardziej znaczących miniaturach Beatos, które świadczą o szerszym projekcie interpretacyjnym księgi Apokalipsy ${ }^{38}$.

Miniatury w Beatos znajdowały się zazwyczaj na końcu komentowanego tekstu. Choć w swoich detalach wydawać się mogą prymitywne (otwarta przestrzeń, seryjna powtarzalność przedmiotów, podział na części, dwoje oczu w twarzy z profilu), to wpisują się jednak, zwłaszcza dzięki doskonałemu oddaniu elementów dramatycznych, w linię wzrastającego postępu sztuki iberyjskiej $^{39}$.

Istotnym czynnikiem dla zrozumienia przesłania miniatur z Beatos są ich nawiązania do kultury islamskiej, które można rozpatrywać na kilku płaszczyznach. $\mathrm{Z}$ jednej strony uderza bezpośrednie nawiązanie do pewnych form sztuki muzułmańskiej (motywy roślinne, symetria), dekoracji architektonicznych (tak często pojawiające się łuki dwukolorowe właściwe dla mezkit), często z kości słoniowej (z czego bardzo słynęła Kordoba). Ponadto liczne instrumenty muzyczne trzymane przez postaci z miniatur są pochodzenia arabskiego. Istotnym tłem teologicznym są również muzułmańskie idee eschatologiczne (podział piekła na kwatery oddzielone łukami, charakter kar ${ }^{40}$ ), a także bezpośrednie nawiązania do Mahometa jako Antychrysta z Apokalipsy ${ }^{41}$. Niejed-

37 Por. M. Perez, Seis estudios sobre beatos medievales, Leon 2010.

38 Istnieje wiele publikacji analizujących program ikonograficzny ilustracji kodeksowych „beato”, wśród których warto zwrócić uwagę zwłaszcza na A. Franco, Las ilustraciones del Beato del monasterio de Santo Domingo de Silos, w: Beato de Silos, Barcelona 2003, s. $73 \mathrm{nn}$.

39 M. Perez, Seis estudios sobre beatos medievales, Leon 2010.

40 J. Yarza, ,El „descensus ad inferos” del Beato de Gerona y la escatología musulmana', Boletín del Seminario de Arte y Arqueología, Universidad de Valladolid, XLIII (1977), s. $135-146$.

41 Szereg tych zbieżności, wpływów, ale też znaczących różnic w obu ikonografiach przedstawia Churruca, Manuela, Influjo oriental en los temas iconográficos de la miniatura española. Siglos X al XII, Espasa-Calpe, Madrid 1939. Wymieniłem jedynie niektóre z nich ze względu na ich znaczenie dla teologicznej interpretacji komentarza Beato. 
nokrotnie możemy spotkać postaci z turbanami, siedzące ze skrzyżowanymi nogami, co jasno ukazuje kontekst społeczno-kulturowy.

\section{Kościoły Apokalipsy}

Motywy eklezjologiczne $\mathrm{w}$ miniaturach $\mathrm{z}$ Beatos dotyczą obrazów siedmiu kościołów w Azji, który stanowią wyrazistą serię miniatur, ale nie tylko: utożsamienie przesłania skierowanego do owych kościołów z Kościołem Powszechnym prowadzi Beato do poszukiwania także innych odniesień skrypturystycznych będących prefiguracjami Kościoła. Dlatego pojawia się w Beatos miniatura "Arki Noego" jako ucieczki, schronienia, dla tych, którzy wcielają w życie (pomimo trudności) nauczanie Ewangelii i okazują się wierni nakazom Pana. Potwierdza ten typ myślenia tekst przytaczany w komentarzu, a pochodzący z dzieła De Arca Noe autorstwa Grzegorza z Elwiry (IV w.). Istotne znaczenie ma także prolog do księgi II, w którym Beato pokazuje Kościół i synagogę, a także ekskurs o Antychryście, pochodzący z De civitate Dei św. Augustyna.

\section{Babilon}

Jedno z wyobrażeń tzw. Wielkiej Nierządnicy Babilonu (Morgan f 194v) pokazuje ją jako kobietę siedzącą $w$ stylu islamskim na poduszce, a w jej nakryciu głowy można dostrzec wyraźne aluzje do półksiężyca ${ }^{42}$. W innej wersji kodeksów siedzi na koniu w charakterystycznym ubiorze właściwym dla Al-Andalus ${ }^{43}$. Znane opisy ogrodów, placów i pałaców w Kordobie, drzew owocowych, fontann wprowadzają element bogactwa, który kusił młodych chrześcijan. Żalił się na nich biskup Kordoby w 854 roku, że zostali „upici arabską elokwencją”, przywiązując małą uwagę do języka łacińskiego i swoich tradycji ${ }^{44}$. Podobnie

42 F. Ruggles, Representation and Identity in Medieval Spain: Beatus manuscripts and the mudejar churches of Teruel, w: R. Brann (ed.), Languages of Power in Islamic Spain, CDL Press, Bethesda 1997, s. 77-95.

43 M. Sepúlveda-Gonzalez, La mujer en el Comentario al Apocalipsis de Beato: la personificación de Babilonia y su interpretación, „Actas del Coloquio Hispano-Francés celebrado en Madrid del 5 al 7 de noviembre de 1984", Madrid 1986, s. 407-430.

44 A. Casiday, 'The sweetest music that falls upon the ear': Translating and Interpreting the Psalter in Christian Andalucía, w: A. Andreopoulos, A. Casiday, C. Harrison (red.), Meditations of the Heart: The Psalms in Early Christian Thought and Practice, Brepols, Turnhout 2011, s. 225-242. Artykuł analizuje trzy postawy względem prób tłumaczeń tekstów biblijnych na język arabski: 1) Albar i jego Indiculus Luminosus pokazuje, że język arabski był tak silnie złączony z religią islamską, że trudno go wykorzystać do przekazu Pisma Świętego. Był zaniepokojony postępującą inkulturacją młodych mozarabów, a także tym, że język arabski - język transakcji handlowych, wysokiej kul- 
„zburzenie Babilonu” (Morgan f.202v) przedstawia bogaty pałac, ozdobiony łukami, pięknymi naczyniami, motywami roślinnymi i geometrycznymi. Pełnia kolorów, brak ludzkich motywów sprawia, ze można utożsamić ów Babilon z kodeksów Beatos z islamskim pałacem. Pokazuje to jednocześnie co kusiło chrześcijan i by się temu oprzeć Beato przytacza apokaliptyczny los Wielkiej Nierządnicy. Przesłanie miniatury było jasne: islam, podobnie jak Babilon, jest ogarnięty przez grzech i pozostaje kwestią czasu jego upadek ${ }^{45}$. Imperium prześladowcy upadnie i na jego ruinach wzniesie się nowa, chwalebna Jerozolima.

\section{Ołtarz i męczennicy}

Zasługuje także na uwagę scena opisywana w Ap 6, 9-11 związana z otwarciem piątej pieczęci ${ }^{46}$. Jest to przedstawienie właściwe wszystkim trzem rodzinom kodeksów Beatos, które w podobny sposób przedstawiają scenę biblijną, skupiając swoją uwagę przede wszystkim na dwóch elementach tej wizji: ołtarzu Boga oraz duszach męczenników. Jest również nawiązaniem do paleochrześcijańskiego obrazu z kościoła w Madabie, do którego wykazuje liczne podobieństwa. Tak zwany Proto-Beato z Silos przedstawia w górnej części ołtarz niebieski, a pod nim wołających o sprawiedliwość męczenników. Ołtarz ma formę tau, dwie lampy po obu stronach, a w niższej części ołtarz horyzontalny i dusze ubrane na biało, oczekujące na swoich towarzyszy. Obok popiersie Boga z otwartymi ramionami czekającego na swoich wiernych wyznawców. Obraz toczy się niejako w dwóch wymiarach: ziemskiej i niebiańskiej, które nie są dwoma różnymi historiami, lecz stanowią istotową jedność.

tury - niszczył resztki kultury rzymskiej (którą utożsamiał z chrześcijaństwem). 2) Natomiast Haf i jego urjuza już nie ma zastrzeżeń ogólnych, a raczej wyraża troskę o dobrą jakość przekładów na arabski. Widział ich niewystarczalność. 3) Praefatio do Psałterza Mozarabskiego (przetłumaczonego na arabski) nie wnika już w kwestie językowe, ale podkreśla wartość psalmów dla podtrzymywania tożsamości chrześcijańskiej. Pokazuje to pewną dynamikę procesu przenikania języka arabskiego (z codzienności) do języka liturgicznego.

45 Por. J.G. Beckwith, Islamie influence on Beatus Apocalypse Manuscripts, „Actas del Simposio de los Códices del commentario al Apocalipsis de Beato de Liébana”, Madrid 1980, s. 55-60.

46 Por. P. Cid, La miniatura de la apertura del Quinto Sello en el Beato de Girona. Estudio comparativo de la serie de los códices, Annals de l'Institut d'Estudis Gironins, XXVII, Gerona 1984, s. 71-75. 
W innych kodeksach miniatura ma potrójną strukturę ${ }^{47}$. W górnej części znajduje się ołtarz otoczony dwiema lampami w kształci alfa i omega, natomiast $\mathrm{w}$ środkowym registrze obrazu pojawiają się gołębice symbolizujące postaci męczenników, które zostają przyjęte i towarzyszą Chrystusowi przedstawianemu z rękoma w geście nie tyle błogosławieństwa, ile dyskursu, choć bez księgi. W dolnej części pojawia się kolejny ołtarz z obliczem Chrystusa (przypominający ikonę), a obok jedna $\mathrm{z}$ lamp podobnych do tych z górnej części miniatury. W dolnym orszaku również pojawiają się męczennicy, nie mają rąk i są odziani w różnokolorowe szaty, a ich czarne oczy wydają się niezwykle ekspresyjnym świadectwem tego, co przeżyli i co przekazują swoją postawą.

Niewiasta i smok

Miniatura ta stanowi jedną z najbardziej przemawiających kompozycji programu ilustracyjnego Beato (która znalazła swój popularny wyraz choćby w powieści U. Eco, Imię róż $\left.y^{48}\right)$. Przedstawia smoka o siedmiu głowach, który dominuje w całym obrazie, a postać niewiasty pojawia się w trzech kontekstach, wedle samego tekstu Apokalipsy. W pierwszym z nich jako stojąca na półksiężycu (co w kontekście islamskiego sąsiedztwa zwracało szczególną uwagę), otoczona wieńcem z dwunastu gwiazd, według opisu Ap 12,1. Na łonie Niewiasty znajduje się słońce. W drugim kadrze tej samej miniatury, w prawym górnym roku, Niewiasta prowadzi syna przed tron Boga, ubi puer raptus est. $\mathrm{W}$ ostatniej odsłonie widzimy ją na pustyni, obdarzoną skrzydłami, jednym wzniesionym ku górze, drugim ku dołowi. Niedaleko niej znajduje się wąż jako zwierzę pustynne, ale także czytelna aluzja do szatana. Jednocześnie miniatura pokazuje kosmiczne starcie sił dobra i zła, obrazowane walką archanioła Michała i jego aniołów przeciw smokowi. Na silny dramatyzm tej sceny wpływają również „mocne” kolory i sama struktura miniatury.

W interpretacji Beato Niewiasta z Apokalipsy, podobnie jak dla egzegezy patrystycznej, nie utożsamia się z figurą Maryi, lecz z Kościołem i być może $\mathrm{z}$ tego powodu jest paradygmatem jego sytuacji ${ }^{49}$. Walka dobra ze złem dokonuje się na jego oczach, w jego codziennych wyborach, a on będąc ziemski i niebiański (skrzydła Niewiasty) jednocześnie, ma świadomość wsparcia ze strony Boga i Jego aniołów.

47 A. Mundó, M. Sánchez, El comentario de Beato al Apocalipsis: catálogo de los códices, Biblioteca Nacional, Madrid 1976.

48 A. Franco, Las ilustraciones del Beato..., s. 139.

49 K. Kinane, M. Ryan, End of Days: Essays on the Apocalypse from Antiquity to Modernity, McFarland Press, Jefferson 2009, s. 47-67. 
Krzyż

Krzyż, niejednokrotnie z przydomkiem „z Oviedo”, zawsze rozpoczynał komentarze Beato, często po obu stronach znajdują się litery alfa i omega. Nad krzyżem pojawia się łuk triumfalny podtrzymywany przez cztery postaci, dwie po obu stronach, przypominające Atlantów, a ich nogi trzymają w paszczach smoki. Dominuje żółty kolor, czerwone linie, a w środku inskrypcja PAX LUX / REX LEX, która nawiązuje do tradycji karolińskiej i Homilii Szmaragdowych z Kordoby (poł. X wieku).

\section{Palma}

Jest jednym $\mathrm{z}$ najbardziej wymownych symboli pojawiających się w komentarzu Beato, a zaczerpniętym z Moralia in Iob św. Grzegorza Wielkiego (XIX,49), gdzie papież wprowadza słynny paralelizm między palmą a życiem sprawiedliwych. Podobnie jak palma, wąska u korzenia i rozłożysta u konarów, tak życie wiernych Ewangelii na tym „dolnym” świecie jest poddane presjom i niejako ściśnięte, a stanie się rozłożyste w górnym świecie zbawionych. U korzenia palma jest twarda i gorzka, ale gałęzie i owoce tego drzewa sprawiają, że staje się czymś pięknym. Podobnie cierpiący prześladowania w tym życiu, maltretowani przez świat, rozkwitną ponownie w nowym świecie. Palma staje się więc metaforą życia cnotliwego, co jest nawiązaniem do Ap 7,9, gdzie mowa o niezliczonej rzeszy ludzi trzymających palmy w ręku. W miniaturach mozarabskich jest przedstawiana $\mathrm{z}$ widocznym, prześwitującym korzeniem oraz najczęściej z siedmioma rozłożystymi ramionami, których liczba nawiązuje do wszechmocy Bożej ${ }^{50}$.

\section{Główne wątki teologiczne komentarza Beato do Apokalipsy}

W swej pracy komentatorskiej nad tekstem Apokalipsy Beato korzysta, jak wspominaliśmy, przede wszystkim z reguł egzegetycznych wypracowanych przez afrykańskiego teologa Tychomiusza. Charakter dzieła - będącego swoistą patrystyczną catena, łańcuchem cytacji z dzieł Ojców Kościoła, ale niezwykle oryginalnie skomponowaną, sprawiającą wrażenie jednolitości, w której głos Beato ukrywa się za przytaczanymi opiniami uznanych autorytetów ${ }^{51}$, ale po-

50 H. Stierlin, Los Beatos de Liébana y el arte mozárabe, Editora Nacional, Madrid 1983.

51 Por. P. Roszak, Autorytet a poszukiwanie madrości. Wokót konceptu auctoritas w teologii św. Tomasza z Akwinu, Człowiek w Kulturze 22 (2011/2012), s. 67-90. Ten progra- 
zostaje przy tym, co istotne, jego własnym - oraz jego program egzegetyczny, bliski hermeneutyce afrykańskiej, wyjaśniają często obecność tzw. rekapitulacji. Była to szósta $\mathrm{z}$ reguł interpretacji Tychomiusza przypominająca, że Biblia często „miesza” ze sobą czasy, przeszły, teraźniejszy i przyszły, a zatem poszczególne księgi Apokalipsy, wedle praktyki Beato, mówią to samo, ale w inny sposób: brevius, clarius, plenius ${ }^{52}$.

\subsection{Paruzja}

Jeden z podstawowych wątków i celów egzegezy Beato to przygotowanie czytelnika na bliski już koniec świata, koniec szóstej epoki (tysiąclecia) świata. Dlatego pragnie przedstawić naukę, która będzie duchowym umocnieniem dla wiernych, ale także posłuży jako materiał homiletyczny dla głoszących kazania w okresie wielkanocnym. Na ten parenetyczno-dydaktyczny cel jasno wskazuje prolog do komentarza: w służbie tak sformułowanego projektu odnajdujemy elementy teologii dogmatycznej, kwestie moralne i duchowe oraz interpretacje biblijne.

Oczekiwania związane z bliskim już rokiem 800, przekonanie o bliskiej paruzji wpisują się w logikę dyskursu Beato na temat Apokalipsy, zawsze jednak trzymającego się ortodoksyjnej interpretacji Pisma Świętego. Ma świadomość, że tylko Bóg zna właściwą chwilę (por. Dz 1,7), że tylko Ojciec zna ów „dzień” (Mt 24,36). To jednak nie przeszkadza, aby na kratach komentarza do Apokalipsy, idąc za przykładem Hieronima, Augustyna czy Juliana z Toledo, podjąć się konkretnych obliczeń: w analogii do sześciu dni stworzenia, uważa, że historia świata toczy się w sześciu epokach. Pięć z nich istniało od stworzenia świata do narodzin Chrystusa, natomiast ostatnia, zgodnie z regułami proporcji, jest już bliska końca. Brakuje niewiele lat do paruzji: w jednych kodeksach mowa jest o 14, w innych o 24 latach, jeszcze innych 16, ale nie wiemy - stwierdza nasz autor - czy ten czas, zgodnie z wyrokiem Opatrzności, nie przedłuży się lub skróci. Niemniej jednak Beato, utrzymując pewien millenaryzm, trzyma się prawowiernej nauki Kościoła, posługując się często sformułowaniami „nie wiemy”, „nie znamy”, ,jedynie wiemy, że Bóg odpoczął siódmego dnia”, choć zdecydowanie optuje za tym, aby tysiąc lat panowania Chrystusa z Ap 20 uznać

mowy szacunek dla auctoritas, właściwy dla mentalności średniowiecza, wyraża się także w obecności często sprzecznych interpretacji fragmentów Apokalipsy, który Beato nie próbuje arbitralnie godzić, lecz zachowuje w ich oryginalnym przesłaniu.

52 A. del Campo, Introducción, w: Beato de Liébana, Obras completas..., s. 15. 
za odnoszące się do tego świata, a wyrażające się w obecności Kościoła aż do końca historii ${ }^{53}$.

\subsection{Antychryst}

Żywiąc przekonanie, że żyje w czasach ostatecznych, na kartach komentarza skupia uwagę na postaci Antychrysta, którego opisuje za pomocą szeregu szczegółów: jest synem konkubiny i pochodzi z pokolenia Dana, będzie nawoływał do powrotu do prawa Mojżeszowego, odbudowując świątynie w Jerozolimie, w której umieści swój wizerunek ze złota. Metodą jego działania będzie doprowadzone do perfekcji uwodzenie dusz oparte na hipokryzji: będzie prowadził na zewnątrz przykładne życie, przez swą wstrzemięźliwość. Po trzech i pół roku rządów (aluzja do długości nauczania publicznego Chrystusa) zginie na Górze Oliwnej.

$\mathrm{Z}$ kart komentarza przebija również inne spojrzenie na temat postaci Antychrysta: są nim wszyscy, którzy nie uznają Chrystusa ${ }^{54}$. Działa w sposób ukryty przez fałszywych chrześcijan i tak rozumiany jest obecny w każdym czasie i epoce. Ale jednak wątek osobowy jest dominujący: Beato przedstawia prekursorów Antychrysta, przytaczając osiem jego imion, jako że siedem głów bestii to siedmiu królów, a sama bestia jest ósma. Już w Summa dicendorum Beato wprowadził ważną formułę hermeneutyczną dla Apokalipsy, która „nigdy nie oddziela czasu teraźniejszego od ostatecznego, w którym pojawi się Antychryst, ponieważ to, co wówczas nastąpi w sposób widzialny, teraz dokonuje się w Kościele w sposób niewidzialny" 55 .

Bez wątpienia Beato chce przygotować chrześcijan, za pomocą komentarza, na ostatnie lata szóstego wieku świata. Ten cel pastoralny, właściwy hiszpańskiej literaturze patrystycznej tego czasu, pojawia się w głównym prologu adresowanym do Heteriusza, gdzie wyjaśnia, że pisze to dzieło nie dla wykazania własnej erudycji (w komentarzu nie brak zresztą pewnej deprecjacji filozofii), lecz „z wiary i pobożności”, dla umocnienia w nadziei.

53 A. del Campo, Introducción, w: Beato de Liébana, Obras completas..., s. 22.

54 J. Guadalajara, El Anticristo en la España medieval, Ediciones del Laberinto, Madrid 2004, s. 24.

55 Comm. in Apoc., Summa dicendorum, 4.: Numquam enim separat praesens tempus a novissimo, que revelabitur Antichristus, quia quod tunc visibiliter fit, nunc invisibiliter in Ecclesia geritur. 


\section{3. „Ku górze”: chrześcijańska droga doskonałości}

Odpowiedzią na próby wierności Ewangelii, jakiej są poddawani chrześcijanie w czasach Beato, jest wejście na drogę doskonałości, którą nasz autor opisuje $w$ ramach pesymistycznej antropologii odziedziczonej po św. Augustynie. Mnich z Liébany również bowiem postrzega człowieka jako „duszę, która posługuje się ciałem" oraz kroczy wiernie za dualistycznym schematem augustynizmu: można odróżnić lud Boży i lud szatana, miasto Boga i miasto diabła, królestwo Boga i królestwo demona. Między tymi dwiema grupami istnieje napięcie i walka przypominająca zmagania wojenne. Są nie do pogodzenia ze sobą, choć granice między nimi nie są do końca czytelne: mogą znaleźć schronienie również $\mathrm{w}$ Kościele, a konkretnie: $\mathrm{w}$ herezji, hipokryzji i wszelkim formom zafałszowanego życia. Zwycięstwo w tej walce na krótki czas przypadnie „światu”, ale ostateczny triumf przypadnie Bogu, który pokona świat rozumiany jako historia damnata. Dlatego przedstawia go jako Wszechmocnego i Sędziego, mniej skupiając uwagi na jego ojcostwie i miłosierdziu.

Do tego zmagania się ze światem Kościół przystępuje wyposażony w broń swej nauki moralnej i dlatego ogólny wydźwięk komentarza jest właśnie parenetyczny, na wzór pism Grzegorza Wielkiego. Beato wychwala trzy cnoty teologalne (wiarę, nadzieję i miłość), które są niczym trzy bramy Nowej Jerozolimy znajdujące się na każdym z czterech punktów kardynalnych ${ }^{56}$. Towarzyszą im inne cnoty, głównie o charakterze ascetycznym, zachęcające do zachowania niezbędnego dystansu wobec dóbr świata, wzywając do pokory i cierpliwości w znoszeniu prób, gorliwego spełniania swoich obowiązków, upominania bliźniego, ale także wstępowania w szeregi składających śluby dziewictwa i czystości oraz nieustannego dbania o czystość intencji.

Droga do doskonałości szkicowana przez Beato jest więc „ucieczką od świata" "57, a realizuje się dzięki pielęgnowaniu u każdego chrześcijanina umiejętności nieprzywiązywania się do dóbr doczesnych i gotowości do zmagania się o dobra wieczne. To pierwszy etap doskonalenia człowieka - drugi bowiem będzie polegał już na pewnym postępie, progressum, który polega na przechodzeniu od tego, co niskie, do tego, co wysokie. Jest to proces duchowego budowania, który dokonuje się dzięki darom Ducha Świętego ${ }^{58}$. Są one niezbędne dla człowieka, który od rzeczywistości ziemskich podnosi się ku niebieskim, idzie drogą od bojaźni Bożej do zdobycia prawdziwej mądrości. 
$\mathrm{Z}$ ideą wstępowania, progresu duchowego, związane jest też podstawowe kryterium egzegezy Pisma Świętego, w której można wyróżnić trzy sensy: historyczno-dosłowny, topologiczno-moralny oraz rozumienie duchowe. W komentarzu Beato do Apokalipsy zostają one porównane do trzech metali: brązu, srebra i złota. Choć celem wszystkich jest osiągnięcie złota, zauważa Beato, to jednak nie powinno się deprecjonować pozostałych, gdyż stanowią „kroki” niezbędne do przejścia drogi doskonałości, a więc do osiągnięcia inteligencji duchowej, utożsamianej z lectio divina. Jest to jednocześnie proces przechodzenie od tego, co materialne, do tego, co duchowe, od życia aktywnego do kontemplacyjnego, od człowieka ziemskiego do człowieka duchowego. Owo najwznioślejsze, duchowe rozumienie Pisma Świętego jest porównane do wody, która stanie się najlepszym winem z Kany Galilejskiej, gdyż pozwoli osiągnąć cel lectio divina - kontemplację, która na razie jest w zwierciadle, to jednak stanie się oglądaniem twarzą w twarz samego Boga ${ }^{59}$.

\subsection{Elementy eklezjologii Beato}

Pomimo dominującego aspektu moralno-ascetycznego komentarza, dzieło Beato zawiera ciekawe i oryginalne elementy interpretacji eklezjologicznej, która czerpie z wielu pism Ojców Kościoła. To właśnie Kościół jest niczym „Zwierciadło hermeneutyczne", w którym odbijają się prawdziwe dzieje świata.

Niezwykle wymownym świadectwem wrażliwości eklezjologicznej Beato będzie interpretacja „niewiasty obleczonej w słońce” jako personifikującej Kościół, w którym rozbłyska chwała zmartwychwstałego Chrystusa. Tę interpretację spotykamy już u Hipolita, potem donatysty Tychomiusza (do którego tak często odwołuje się Beato), ale także u współczesnych naszemu autorowi jako choćby u Bedy Czcigodnego.

Obraz niewiasty wyraża tajemnicę Kościoła w różnych etapach jego istnienia, gdyż perspektywa eklezjologiczna Beato jest szeroka, przekonana o Ecclesia ab Abel. Niewiasta z Ap 12,1 wyobraża zatem Kościół patriarchów, proroków i apostołów, który oczekiwał z utęsknieniem Chrystusa - a więc Kościół „brzemienny” w nadzieję zmartwychwstania, którą wyobraża słońce. Księżyc ze swoim cyklem wzrastania do pełni i potem zanikania na niebie jest symbolem prześladowań, które $\mathrm{z}$ różną intensywnością spotykają świętych żyjących wśród niebezpieczeństw doczesnego czasu. Ale jak księżyc pośrodku nocy pozwala wędrowcom orientować się przy wyborze właściwych dróg, tak święci jaśnieją pośród trudności dzięki swej wytrwałości. Natomiast korona z dwunastu gwiazd to chór patriarchów Izraela, z których wedle ciała będzie pochodził

59 Comm. in Apoc., III, 3. 
Chrystus. Jak zauważa Beato, „mówiąc o tej kobiecie odnosi się do Kościoła, który nosi Chrystusa na swoim łonie. Ponieważ Kościół rodzi [wiernych] w wielkich bólach i pragnie naśladować Chrystusa" ${ }^{" 60}$.

Pojawiający się w tej samej scenie smok ognisty jest dla Beato metaforycznym obrazem starań Złego, aby wyrwać Chrystusa z życia chrześcijan. Aby to osiągnąć, nieraz posługuje się w tym celu „złymi chrześcijanami”, a więc żyjącymi w grzechu i dalekich od prawowiernej doktryny. To oni stanowią ów „ogon” smoka, który zmiata trzecią część gwiazd z nieba, to znaczy świętych (niebo jest symbolem Kościoła), którzy ulegając ich wpływom stają się „ziemskimi”61. Narodziny syna to nieustanne rodzenie Chrystusa i budowanie w ten sposób całego Ciała, gdyż Chrystus jest Głową i ze wszystkim innymi stanowi jedno Ciało (cum Ecclesiae membris unus corpus est Christus), co jest wyraźną aluzją do augustyńskiej idei Christus totus ${ }^{62}$. Według interpretacji Beato, podkreślenie, że porodziła „mężczyznę” jest nawiązaniem do Proto-Ewangelii z Księgi Rodzaju. Natomiast ucieczkę na pustynię, rozumianą jako miejsce skorpionów i wężów (czyli złych ludzi, którzy nie przyjmują Ewangelii), odczytuje w perspektywie obietnicy Pana z Łk 10,19: Oto dałem wam władzę stapania po wężach i skorpionach. Oznacza to jasny przekaz dla mozarabskich chrześcijan: Kościół realizuje swą misję na trudnej „pustyni” doczesnego czasu, pośród wielu fałszywych proroków, którzy symulują przylgnięcie do jego nauki, a w rzeczywistości stanowią poważną opozycję do jego misji. Zadanie Kościoła polega na otwieraniu drogi dla Chrystusa przy świadomości, że prawdziwy pokarm dla swego życia i misji czerpie od samego Boga i to od Niego przyjdzie jego prawdziwe wyzwolenie w dni paruzji. Dla Beato to aluzja do Izraela, którego również śmiercionośne węże kąsały na pustyni (Lb 21,8-9) i ocalał dzięki prefiguracji Krzyża.

\section{Podsumowanie}

Refleksje nad teologicznym przesłaniem komentarza Beato do Apokalipsy powinny uwzględniać zarówno wykładnię tekstu dokonaną na podstawie inter-

60 Comm. in Apoc., Summa dicendorum, 5: Hanc mulierem Ecclesiam dicimus, quae Christum in utero habet. Quia Ecclesia cum grandi gemitu parturit, quae Christum imitari cupit.

61 Comm. in Apoc., VI, 2.

62 Więcej o egzegezie augustyńskiej: P. Bright (red.), Augustine and the bible,: University of Notre Dame Press, Notre Dame 1997; M. Harl, Le déchiffrement du sens: études sur l'herméneutique chrétienne d'Origène à Grégoire de Nysse, Institut d'études augustiniennes, Paris 1993; F. Van Fleteren, Augustine: biblical exegete Peter Lang, New York 2001. 
pretacji Ojców Kościoła, jak elementy iluminatorskie towarzyszące tekstowi. Stanowią one metodologiczną jedność i pozwalają na komplementarne traktowanie „miniatur” i „tekstu”, które razem mają ułatwiać lectio divina. Bogaty w starotestamentalne nawiązania, Commentarius in Apocalypsin to niezwykły projekt hermeneutyczny, który odczytuje przesłanie Apokalipsy na tle historii zbawienia i jednocześnie, troszcząc się o ortodoksyjność interpretacji, pokazuje jej spełnianie się w konkretnych epokach dziejów świata.

Komentarz ma charakter ascetyczno-mistyczny, wytyczający właściwy szlak dla chrześcijańskiej egzystencji, która realizuje się w środowisku nieprzychylnym dla Ewangelii. Dlatego wymaga się od uczniów Chrystusa czujności i umiejętności odróżniania znaków, które odsłonią prawdziwe intencje fałszywych świadków wybierających drogę zła i tym samym nie skłonią się ku ich namowom.

Zdaniem mnicha z Liébany, to Kościół i jego misterium stanowi klucz interpretacyjny do księgi Apokalipsy. Ta księga bowiem wyjaśnia sens doczesnych zmagań, trudności i prześladowań doświadczanych przez Kościół, które nie osłabiają jednak jego wierności, lecz umacniają na drodze doskonałości. Przebija z linii komentarza troska, aby Kościół pozostał sobą, aby szukał swej tożsamości w Chrystusie, zdał sobie sprawę, że zbawienie może okazać się kwestią ofiary i poświęcenia, ale nade wszystko to wezwanie do odkrycia "sensu”, który drzemie w wydarzeniach historii.

Ale jednocześnie dla Beato, Apokalipsa jest krzykiem nadziei, który wzywa do odkrycia w Chrystusie ostatecznego fundamentu życia, ponieważ to On będzie definitywnie królował, gdy ponownie przyjdzie w chwale. Eschatologiczne ukierunkowanie życia, które toczy się pośród napięć, nie daje się pomyśleć w oderwaniu od zbawiennego wysiłku, aby okazać się wiernym, gdy szaleje niewierność. To chrześcijańskie życie mierzone miarą nadziei jest brzemienne w zwycięstwo, którym jest osiągnięcie ojczyzny, niebieskiej Jerozolimy.

\section{Summary}

One of original interpretations of a Book of Apocalypse, based on harmony of text and art of mozarabs' miniaturists is commentary of Beato of Liébana, cantabrian monk in VIII century, whose work is until now practically unknown for polish researches. The theological interest in the last book of New Testament among mozarabic Christians has its roots in ecclesiological hermeneutics, which allows read message of Apocalypse as a call to the Church to remain faithful to the testimony of Jesus in each events of his difficult history. This work of Beato belongs to the specific types of catenae, exegetical chains, which recall the previous patristic interpretations of Apocalypse, but without 
abandoning the originality of the interpretation marked by the context of islamic culture. In his structure, the commentary is preceded by four prologues, and followed by storiae and explanatio. In article were also shown selected interpretations of mozarabic miniaturists (Churches of Apocalypse, the dragon and women, Church in heaven and martyrs etc.) and main theological theme (parousia and figure of antichrist). Reach in numerous Old Testament's ecclesiological motives, Commentarius in Apocalypsin of Beato has ascetic-mystical character, setting out the adequate path for Christian existence, which shall be pursued in an unfriendly environment for Gospel. It is therefore required from the discipline of Christ the activity of vigilance and the ability to distinguish signs of the time (signa temporis), which permit to decode the real intentions of false witnesses which goes through the way of evil. 